\title{
SCIENCE AND EDUCATION FOR SMART GROWTH IN THE CONTEXT OF THE INNOVATIVE STRATEGY FOR INTELLIGENT SPECIALIZATION OF THE REPUBLIC OF BULGARIA
}

\author{
Venelin Terziev ${ }^{1}$ and Margarita Bogdanova ${ }^{2}$ \\ ${ }^{1}$ Academician of the Russian Academy of Natural History, Moscow, Russia, Prof. \\ D.Sc.(Ec.), D.Sc. (National Security), D.Sc. (Social Activities), Ph.D., National Military University, \\ Veliko Tarnovo, Bulgaria; University of Rousse, Rousse, Bulgaria, terziev@skmat.com \\ ${ }^{2}$ Prof. Ph.D., D.A. Tsenov Academy of Economics, Svishtov, Bulgaria, \\ mbogdanova@uni-svishtov.bg
}

\begin{abstract}
The report presents a comparative analysis of different policies and approaches for management of centers of excellence (CoE) and centers of competence ( $\mathrm{CoC})$ in the context of the convergence of science and technology policy. The potential challenges to its successful implementation in Bulgaria are outlined. Best practices and management models in the USA, UK, Denmark and Finland are discussed. Among the main problems in Bulgaria are the short horizon of integration between the efforts of universities and research organizations on the one hand, and business and public sector on the other, the lack of private investments for the development of research, the need for reforms in higher education aimed at improving the quality of education.
\end{abstract}

Keywords: Centers of excellence (CoE), Centers of competence (CoC), convergence of scientific and technological policy.

\section{INTRODUCTION}

In the resent years, the subject of convergence in the scientific and the technological policy grows more and more topical and significant for the development of an economy and even society, based on knowledge. Universities' and research organizations' efforts integration on one hand, and of the businesses and the public sector's on the other hand, becomes a key circumstance for building capacity for innovations. According to some estimation, this is the third economic revolution in human history, which is expected to radically change the way of making business, the environment for living's qualities and the society as a whole.

In this complicated, dynamic environment, higher schools and the research organizations acquire bigger and bigger role of a motor and initiator of development. They are part of the "triple helix" that embraces the system „university - business - government”. They perform the so called „third mission”, directed towards encouraging the relations with users of knowledge and towards facilitating the technologies transfer. This new higher schools social role puts them in front of series of challenges that could be over taken through innovative approaches and use of all possible tools for facilitating the knowledge and technologies transfer. 
The Centers of Excellence and the Centers of Competence, which are to be established in Bulgaria in the following years, are among the most modern possibilities for intervention up to now.

The topic about the Centers of Excellence ( $\mathrm{CoE})$ and Centers of Competence $(\mathrm{CoC})$ is perhaps the most update and significant for the higher schools at home to the very present moment. It is in the agenda of Operative Programme „Science and Education for Smart Growth“ (OP SESG) and of many higher schools that elaborate project documentation and prepare for managing multi-disciplinary research centers with high potential for scientific results in priority for the country subject fields.

That is why the scientific community's excitement and the expectations of all interested parties for the results and impact of this type of initiatives are great. Beside the planned direct results such as number of publications and hired researchers, in a longer term plan it is expected for the whole picture of scientific infrastructure to change, conditions for successful career for young researcher to be established and the significance of higher schools and research institutions for the development of economy based on knowledge to change.

\section{INTELLIGENT SPECIALIZATION}

Intelligent specialization is a strategic approach towards the economic development through purposeful support for scientific researches and innovations. It is in the base of the European structural and investment funds interventions in the field of research and innovations as a part of the contribution of the current national policies and the cohesion policies according to the Growth and Employment Strategy Europe 2020. Intelligent specialization includes process of elaborating vision, identifying the competitive advantages, defining strategic priorities and use of intelligent policies for maximizing the potential for development, based on the knowledge of each region. The Innovation strategy for intelligent specialization is based on the „process of entrepreneurial discovery" for defining the economic priorities within the scientific-research and innovation activities, aiming establishment of competitive advantage through development and complying own strong aspects in scientific research with the needs of industry. The goal is to meet the new market's possibilities and changes, concentrating investments in the fields that ensure economy's added value increasing and its competitiveness on the international markets. ISSS in its essence is a process that would continue during the entire programme period 2014-2020.

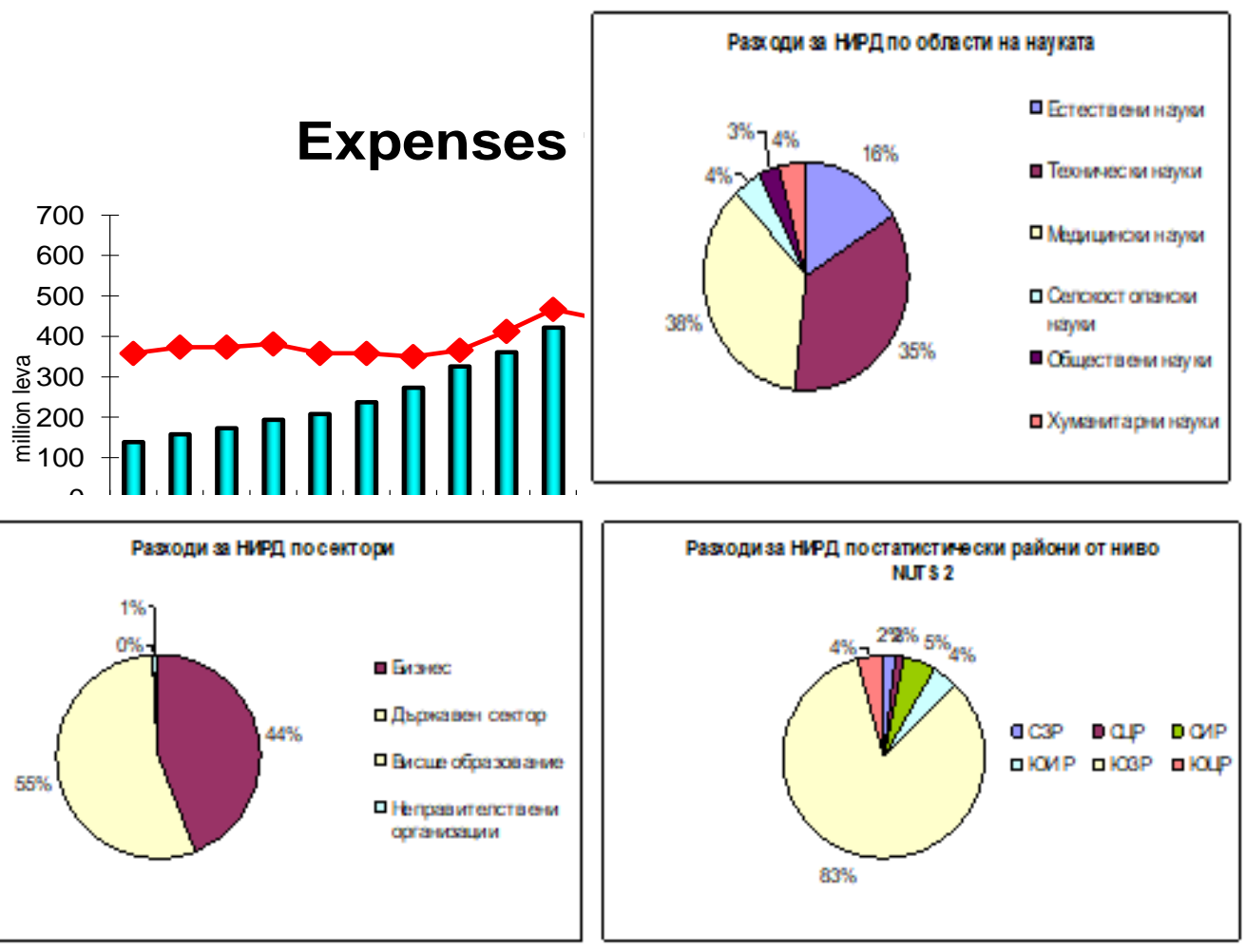

Fig. 1. Expenses for SRDA

The analysis made in the ISSS action plan allows drawing some important conclusions:

- The expenses for SRDA are still insufficient; 
- The expenses for SRDA are predominantly concentrated in the field of medicine, technical and natural sciences $(89 \%)$;

- $\quad$ Business considers the need of expenses for SRDA;

- $\quad$ Business's expenses for SRDA are mainly in the processing industry (about $52 \%$ );

- The expenses for SRDA are distributed quite unevenly by regions $-83 \%$ are in the Southwestern region.

The vision of the Innovation strategy for intelligent specialization of the Republic of Bulgaria is: "To the year 2020, Bulgaria to make a quality leap in its innovation presentation at level EU for coping with the social challenges in the field of demography (reducing brain-drain, attracting the successfully established Bulgarians, stimulating youth entrepreneurship), sustainable development, intellectual capital and nation's health".

Strategic goal: To the year 2020 Bulgaria to move from the group of „timid innovators” to the group of "moderate innovators".

Practically this change in indicators would take place at an effective policy encouraging the following:

- Innovations, scientific research and human capital development,

- Investments in highly technological fields, where Bulgaria has traditions, has established experts and is successfully competing on the international market,

- Export-oriented industries.

The strategic goal would be achieved with achieving two operative goals:

Goal 1: Focusing the investments for developing innovative potential in the identified subject fields (for establishing and development of new technologies, leading to competitive advantages and increasing national products and services added value)

Goal 2: Support for accelerated mastering of technologies, methods, etc. that improve resource effectiveness and the application of ICT in all industries enterprises.

The process of intelligent specialization identification is dynamic, with the participation of partners from the economic and the scientific fields as well as the civil society in order to identify the fields, where the country has chance to be distinguished and to demonstrate its face on the international market.

The measures undertaken for continuing the process of entrepreneurial discovery would allow the fields, where there is potential for growth and which would contribute most for solving social-economic challenges in front of society to be supported.

The subject fields for intelligent specialization identification is grounded on the principle "from technological to subject fields for intelligent specialization" (Fig. 2 and 3, Table 1).
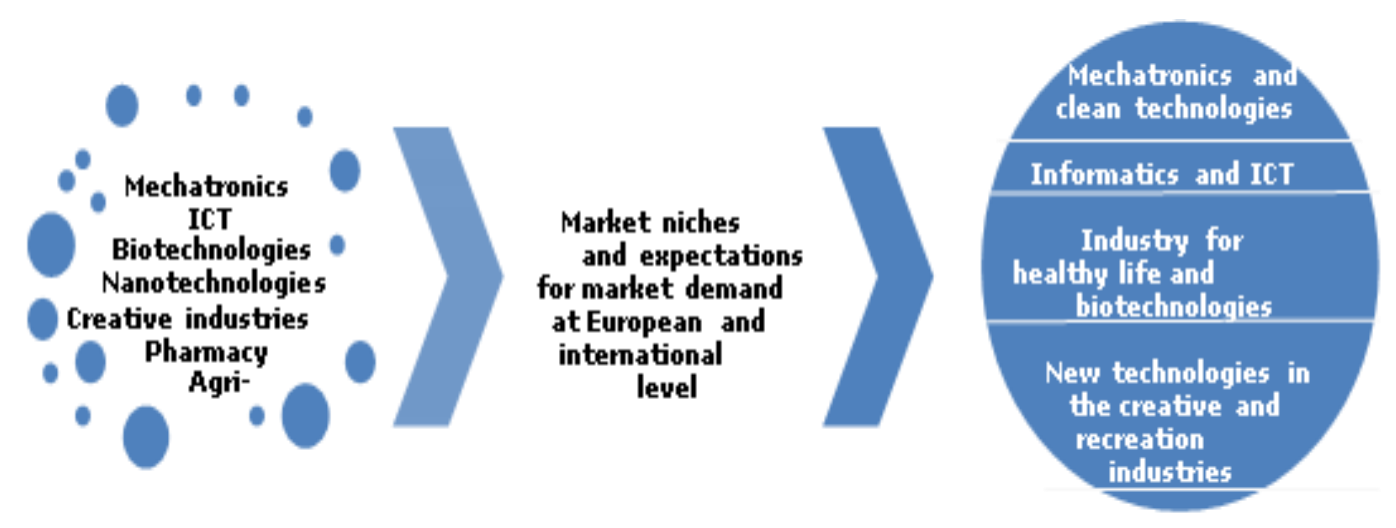

Fig.2. From technological to subject fields of intelligent specialization 


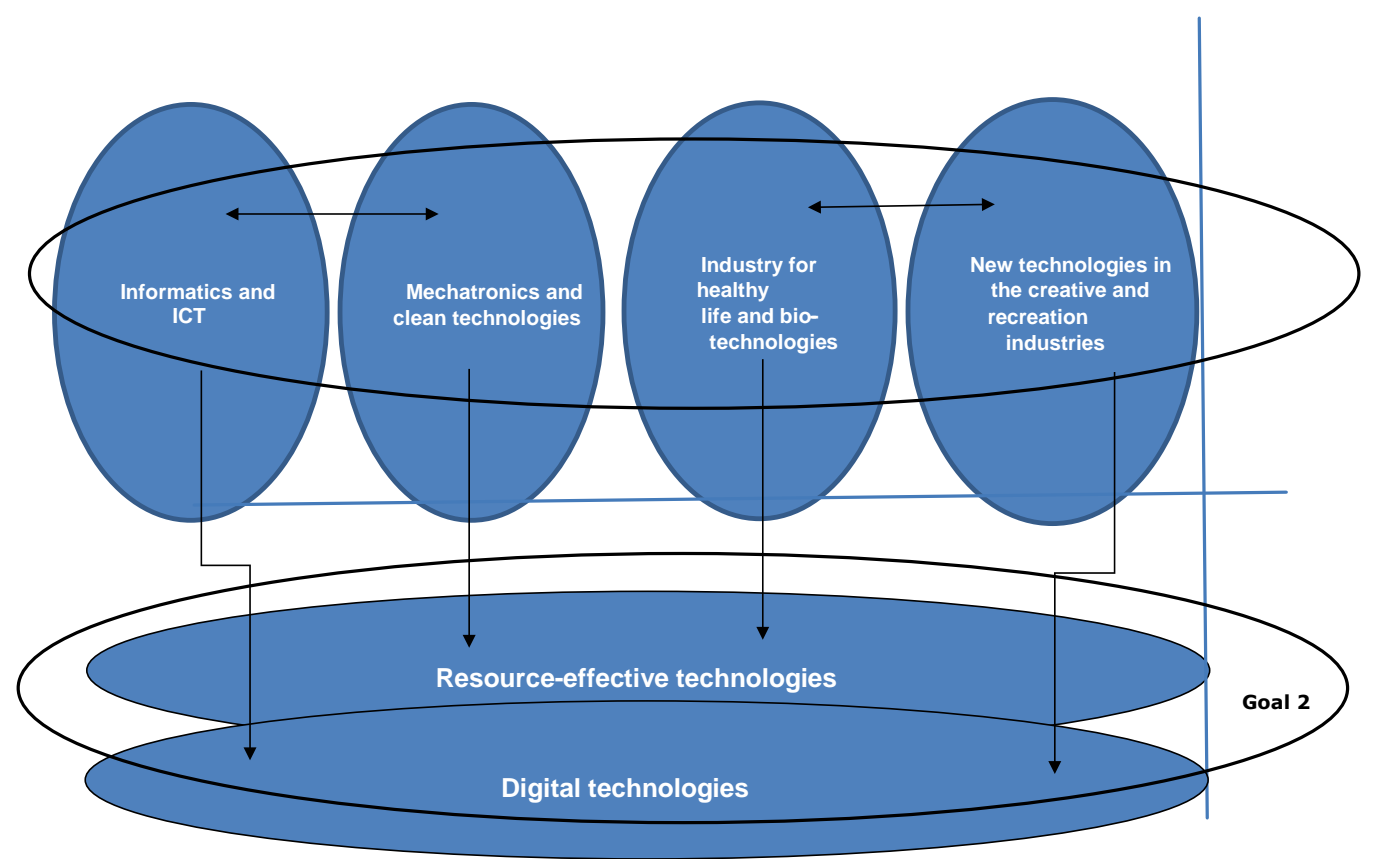

Fig. 3. Scope of ISSS operative goals

Table 1. ISSS subject focus.

\section{Informatics and ICT}

- $\quad$ productions, particularly Fabless and new approaches for design and/or assembling;

- $\quad$ ICT approaches in machine building, medicine and creative industries (in connection with the other three subject fields), including digitalization of cultural-historical heritage, entertaining and educational games, "embedded" software;

- 3D digitalization, visualization and prototyping;

- $\quad$ Big Data, Grid and Cloud Technologies;

- Wireless sensor networks and wireless communication/management;

- $\quad$ Language technologies;

- Web, hybrid and "native" applications, web based applications for establishing and exploitation of new services and products;

- Use of new possibilities in connection with outsourcing and ICT-based services and systems.

\section{Mechatronics and clean technologies}

- $\quad$ production of base elements, details, nodes and equipment, integrated as part of mechatronic aggregate or independently composing such aggregate;

- machine-building and device-building, including parts, components and systems, with stress on transport and energetics;

- $\quad$ engineering, re-engineering and continuing the life cycle of industrial machines, devices and systems;

- $\quad$ robotics and automatization of projects;

- design and production of highly technological products and/or participation in over-national production chain, including in aerospace industry;

- bio-mechatronics;

- intelligent systems and devices, „,intelligent homes" - "intelligent towns";

- clean technologies with stress on transport and energetics (storing, saving and effective energy distribution, electric vehicles and eco-mobility, hydrogen based models and technologies, non-waste technologies, technologies and methods for waste products and materials from one productions to other). 
Industries for healthy life and biotechnologies

- $\quad$ Production, storage, processing and reaching the end user of specific Bulgarian ingredients, items and products (including yoghurt, honey and bee products, bread, beer, wine, dairy and meat products, essential oils, herbs and herbal products, cosmetic items and products);

- $\quad$ Production of specialized food and beverages (baby's and children's, ,space“ food);

- $\quad$ Production of instruments, equipment, consumables for medical and dental diagnostics and therapy and/or participation in supranational production chain;

- $\quad$ Personal medicine, diagnostics and individual therapy, curative and medical forms and items;

- $\quad$ Medical and curative tourism with a stress on the possibilities for personalization (non-mass, but personal);

- nano-technologies in service of medicine;

- bio-technologies with direct application for healthy lifestyle;

- „blue“ technologies and application of new methods and technologies in river and sea resources sustainable use;

- $\quad$ Production of installations for ecologically clean energy and industrial water;

- Green economy - technologies, products, processes.

\section{New technologies in creative and recreation} industries

- cultural and creative industries (according to EC definition: architecture, archiving activities and librarianship, artistic craftsmanship, audio-visual forms (movies, TV, video games and multimedia), cultural heritage, design, including fashion design, festivals, music, stage and visual arts, publishing, radio;

- computer and mobile applications and games with educative, marketing and/or entertainment characteristicsc;

- $\quad$ alternative (rural, eco-, cultural, festival) and extreme tourism and sport (for stimulating non-seasonal but continuous niche tourism);

- $\quad$ production of goods and appliances with direct application in these fields (e.g. national (regional) folklore costumes, bicycles, climbing walls and other goods for alternative and extreme sports, costumes, scene-sets, materials for historical re-enactments, specialized outfit and equipment, printed materials).

Table 2. Subject fields' regional focus

\begin{tabular}{|l|l|l|}
\hline \multicolumn{1}{|c|}{ Northwestern region } & \multicolumn{1}{|c|}{ North central region } & \multicolumn{1}{c|}{ Northeastern region } \\
\hline $\begin{array}{l}\text { Mechatronics and clean } \\
\text { technologies }\end{array}$ & $\begin{array}{l}\text { Mechatronics and clean } \\
\text { technologies }\end{array}$ & $\begin{array}{l}\text { Mechatronics and clean } \\
\text { technologies }\end{array}$ \\
\hline $\begin{array}{l}\text { Industry for healthy life and } \\
\text { biotechnologies }\end{array}$ & $\begin{array}{l}\text { Industry for healthy life and } \\
\text { biotechnologies }\end{array}$ & $\begin{array}{l}\text { Industry for healthy life and } \\
\text { biotechnologies }\end{array}$ \\
\hline $\begin{array}{l}\text { New technologies in the creative } \\
\text { and recreational industries }\end{array}$ & Informatics and ICT & $\begin{array}{l}\text { New technologies in the creative } \\
\text { and recreational industries }\end{array}$ \\
\hline Southwestern region & South central region & \multicolumn{1}{|c|}{ Southeastern region } \\
\hline Informatics and ICT & Informatics and ICT & $\begin{array}{l}\text { New technologies in the creative } \\
\text { and recreational industries }\end{array}$ \\
\hline
\end{tabular}


IJASOS- International E-Journal of Advances in Social Sciences, Vol. V, Issue 13, April 2019

\begin{tabular}{|l|l|l|}
\hline $\begin{array}{l}\text { New technologies in the creative } \\
\text { and recreational industries }\end{array}$ & $\begin{array}{l}\text { Mechatronics and clean } \\
\text { technologies }\end{array}$ & $\begin{array}{l}\text { Mechatronics and clean } \\
\text { technologies }\end{array}$ \\
\hline $\begin{array}{l}\text { Industry for healthy life and } \\
\text { biotechnologies }\end{array}$ & $\begin{array}{l}\text { Industry for healthy life and } \\
\text { biotechnologies }\end{array}$ & $\begin{array}{l}\text { Industry for healthy life and } \\
\text { biotechnologies }\end{array}$ \\
\hline
\end{tabular}

Table 3. Policies and tools for ISSS 2014-2020 implementation

\begin{tabular}{|c|c|c|c|c|}
\hline Indicative activities & \multicolumn{2}{|l|}{ Tool } & $\begin{array}{l}\text { Planned source of } \\
\text { financing }\end{array}$ & $\begin{array}{l}\text { Indicative budge } \\
2014-2020\end{array}$ \\
\hline \multicolumn{5}{|c|}{$\begin{array}{l}\text { GOAL 1: Focus on the innovation potential in the identified subject fields (for new technologies } \\
\text { establishment and development, which would result in competitive advantages and increasing national } \\
\text { products and services added value) }\end{array}$} \\
\hline \multicolumn{5}{|c|}{ SUB-GOAL: Effective cooperation science-business } \\
\hline \multirow{4}{*}{\multicolumn{2}{|c|}{ Cooperation stimulating }} & $\begin{array}{lc}\text { Grant scheme } & \text { for } \\
\text { innovations } & \text { in } \\
\text { enterprises } & \end{array}$ & $\begin{array}{l}\text { Operative } \\
\text { Programme } \\
\text { Innovations and } \\
\text { Competitiveness } \\
\text { /Horizon 2020/ }\end{array}$ & \multirow[t]{4}{*}{$\begin{array}{l}460 \text { million } \\
\text { Euro }\end{array}$} \\
\hline & & $\begin{array}{l}\text { Grant } \\
\text { schemes/vouchers for } \\
\text { joint projects }\end{array}$ & $\begin{array}{l}\text { OPIC /Horizon } \\
2020 /\end{array}$ & \\
\hline & & $\begin{array}{l}\text { Grant schemes for } \\
\text { mediation } \quad \text { (clusters, } \\
\text { OTT, technological } \\
\text { centers) }\end{array}$ & $\begin{array}{l}\text { OPIC, National } \\
\text { Innovation Fund, } \\
\text { National Science } \\
\text { Fund } \\
\text { / Horizon 2020/ }\end{array}$ & \\
\hline & & $\begin{array}{l}\text { Stimulation of offering } \\
\text { quality researches }\end{array}$ & $\begin{array}{l}\text { NIF, NSF } \\
\text { / Horizon 2020/ }\end{array}$ & \\
\hline $\begin{array}{l}\text { Purposeful efforts } \\
\text { encouraging cooperation }\end{array}$ & for & $\begin{array}{l}\text { Centers of competence, } \\
\text { centers of excellence, } \\
\text { Regional } \\
\text { centers }\end{array}$ & OP SESG & $\begin{array}{l}350 \text { million } \\
\text { Euro }\end{array}$ \\
\hline \multicolumn{5}{|c|}{ SUB-GOAL: Quality human resource } \\
\hline $\begin{array}{l}\text { Strengthening the con } \\
\text { between HE and the } \\
\text { market requirements; stin } \\
\text { training in technical and e } \\
\text { specialties; strengthening } \\
\text { education practical applice }\end{array}$ & $\begin{array}{l}\text { hection } \\
\text { labour } \\
\text { ulating } \\
\text { gineer } \\
\text { higher } \\
\text { ion }\end{array}$ & $\begin{array}{l}\text { Support for practices, } \\
\text { Ph.D. candidates and } \\
\text { post-Ph.D. candidates, } \\
\text { scholarships and } \\
\text { distinctions, schemes } \\
\text { for knowledge, skills } \\
\text { and qualification }\end{array}$ & $\begin{array}{l}\text { OP SESG, other } \\
\text { EU programmes }\end{array}$ & 90 million Euro \\
\hline
\end{tabular}


IJASOS- International E-Journal of Advances in Social Sciences, Vol. V, Issue 13, April 2019

\begin{tabular}{|c|c|c|c|}
\hline & enhancement & & \\
\hline \multirow{2}{*}{$\begin{array}{l}\text { Vocational education and } \\
\text { qualification reformation and life- } \\
\text { long learning encouragement }\end{array}$} & $\begin{array}{l}\text { Schemes for vocational } \\
\text { training and qualification }\end{array}$ & \multirow[t]{2}{*}{$\begin{array}{l}\text { OP SESG, other } \\
\text { EU programmes }\end{array}$} & \multirow[t]{2}{*}{50 million Euro } \\
\hline & $\begin{array}{l}\text { Support for informally } \\
\text { acquired knowledge and } \\
\text { skills recognition }\end{array}$ & & \\
\hline $\begin{array}{l}\text { Internationalization of innovations } \\
\text { for additional scientific-research } \\
\text { activity enhancement and } \\
\text { mastering the phenomenon } \\
\text { "brain-drain " }\end{array}$ & $\begin{array}{l}\text { Support for participation } \\
\text { in international projects }\end{array}$ & $\begin{array}{l}\text { Operative } \\
\text { programme } \\
\text { Human } \\
\text { Resources } \\
\text { Development, OP } \\
\text { SESG, other EU } \\
\text { programmes }\end{array}$ & 70 million Euro \\
\hline \multicolumn{4}{|c|}{$\begin{array}{l}\text { SUB-GOAL: Adequate environment and infrastructure for innovations, including digital growth and e- } \\
\text { government }\end{array}$} \\
\hline $\begin{array}{l}\text { Development of adequate } \begin{array}{r}\text { and } \\
\text { secure environment }\end{array} \text { for } \\
\text { innovations creation and } \\
\text { dissemination }\end{array}$ & $\begin{array}{l}\text { Sofia Tech Park } \\
\text { Innovative services for } \\
\text { the business }\end{array}$ & OPIC & $\begin{array}{l}40 \text { million Euro } \\
20 \text { million Euro }\end{array}$ \\
\hline $\begin{array}{l}\text { E-infrastructure and } \quad \text { e- } \\
\text { government }\end{array}$ & $\begin{array}{l}\text { E-government } \\
\text { E-justice }\end{array}$ & $\begin{array}{l}\text { Operative } \\
\text { Programme Good } \\
\text { Governance }\end{array}$ & $\begin{array}{l}140 \quad \text { million } \\
\text { Euro } \\
\text { 35million Euro }\end{array}$ \\
\hline \multicolumn{4}{|c|}{$\begin{array}{l}\text { GOAL 2: Support for accelerated mastering of technologies, methods, etc. that improve resource } \\
\text { effectiveness and the ICT application in all industries enterprises }\end{array}$} \\
\hline \multicolumn{4}{|c|}{ SUB-GOAL: Innovations for resource effectiveness } \\
\hline $\begin{array}{l}\text { In the field of waters } \\
\text { In the field of waste } \\
\text { Information and publicity }\end{array}$ & & $\begin{array}{l}\text { OPIC, ОПОС } \\
\text { /Norwegian } \\
\text { Programme, NIF, } \\
\text { Horizon 2020/ }\end{array}$ & 40 million Euro \\
\hline \multicolumn{4}{|c|}{ SUB-GOAL: Innovations for ICT applications introduction } \\
\hline \multicolumn{2}{|c|}{$\begin{array}{l}\text { ICT applications in the whole industry (software applications, } \\
\text { system software, software for development }- \text { tools for } \\
\text { computer programming) }\end{array}$} & $\begin{array}{l}\text { OPIC, } \\
\text { /Horizon } 2020 \\
\text { NIF, EXCELL / }\end{array}$ & 80 million Euro \\
\hline
\end{tabular}

ISSS offers system for identification and support of the intelligent specialization fields such as:

- Engages leading entrepreneurs and partners in the development and innovative activities from scientific circles and business;

- Concentrates on the national specialization fields support; 
- Integrates the process from bottom-upwards and from top-downwards;

- Is grounded on data and facts;

- Concentrates the expenses for scientific research and innovations by eliminating non-profitable phenomena like fragmenting and duplicating of funds for research;

- Points cross-sectoral fields of specialization;

- Creates conditions for increasing private investments in scientific research and innovations.

Improving the cooperation between research institutes and the business would require combinations of approaches for "active demand" and "quality (scientific) supply". Good cooperation requires relevant infrastructure (2018a-0; 2012a; Dag Aksnes , 2012b; Etzkowitz, Leydesdorff, 1998a; Etzkowitz, 2000a; Gulbrandsen, Slipersaeter, 2007a; Miller, McAdam, McAdam, 2014a; Lemola, 2002a; 2017a-b; 2010a).

\section{CONCLUSION}

Negative trends connected with scientific and innovation activities' development in the country as well as the educational system, and particularly higher education, are the grounds for number of important issues, which solution requires systematic approach.

First, it is necessary to give priority to the investments in infrastructure that contribute to specialization in the ISSS fields.

Second, it is necessary to establish national system for using big scientific-research infrastructures, established with public funds - with publicly accessible map of scientific equipment, clear rules for its use, wide access for the public organizations and the business, maximum effectiveness and unified system for the public results distribution.

Third, it is necessary to support the leading regional universities and scientific centers in order them to adapt to the new ISSS priorities - this would require modernization of their laboratories and equipment for scientific research, in order their scientific research capacity to improve and to be given opportunity to render the relevant business-oriented services.

Like most of the tools, if applied separately, CoE and CoC would not be able to solve all problems of scientific research development in Bulgaria, but would contribute to partly overcome the crisis with the lack of financing in favour of innovative, transformation focused projects.

$\mathrm{CoE}$ are initiatives that stimulate the elitist character of research. That is why achieving public consensus is important for balancing and overcoming of elitist attitudes for financing each one but with little. Precisely such is the problem of the system in Bulgaria - conflict of egalitarian approach of training financing and the elitist character of scientific research financing.

Because of the present publication limited volume and the great number of problems that are to be covered, issues like the following are left outside the scope of the report:

Assessment of the impact of $\mathrm{CoE}$ and $\mathrm{CoC}$, which is to be made as well as scenario of the possible changes in the field of Higher Education;

The business models of $\mathrm{CoE}$ and $\mathrm{CoC}$ management, which are to be completely different from the ones for the higher schools, where they would be unfolded;

Models of successful partners relationships in the $\mathrm{CoE}$ and $\mathrm{CoC}$, where there are consortiums of several organizations;

Necessary competencies for network work with representatives of NGOs, the public sector and the business, etc.;

Business's attitude, what is the extent of it readiness to participate and to invest;

Place of university students in scientific-research projects, etc.

Yet, at the stage of applying, all teams of $\mathrm{CoE}$ and $\mathrm{CoC}$ should include experts with good prognostic skills in order to adequately assess the perspectives for realization of innovative products and research results. Prognostics have to be based on combination of quantity and quality methods. Only this is a serious and responsibility requiring task that requires expertise and experience in scientific-research prognostication and such experts are not available often.

Some important problems have to be solved in short and long term: 
The mandatory trainings that would be organized under technical aid under OP SESG have to include trainings in organizational management of programmes and projects, rules for monitoring and report of results, communication strategies, procurement, etc. Otherwise, organizations, especially when they are in consortium, take the risk of making costing mistakes and of being forced to reimburse funds after they are already spent.

Perhaps at a future stage, when conclusions are drawn for the present procedure weaknesses and when administrative capacity is accumulated in the managing body as well as in the potential beneficiaries, it would be possible to move to two-stage procedure, where only concept is submitted at the first stage, and the detailed development of the project is made at the second stage. This would relieve the process of preparation and beside that, the attention would be entirely directed to the research programme quality and innovativeness, without focusing on capacity that much during the first stage of applying.

It is of quite a significance the relevant reforms in higher education to be undertaken for they would solve at least partially the problem with the quality of training in educational-qualification degree "bachelor" and educational-qualification degree "master". Research sector, which anyway suffers lack of trained and motivated candidates and talents-drain, cannot be supplied without availability of well-prepared cadres. In that regard, stimuli for university student inclusion in scientific-research projects are necessary. The initiative "Science Shop" could be introduced for more young people to be attracted to the field of science.

Part of these preliminary conditions for scientific research success are developed also in the draft for National Strategy for Scientific Research Development to 2025, and in Operative Programme Science and Education for Smart Growth, but not always the technology and mechanisms for their achieving are clear.

The change in the way of universities' management is one of the possible effects from CoE and CoC. For the first time in our country there would be possibility to establish the so called "entrepreneurial universities" and to apply, although to quite a conditional extent, the approaches of the new public management in higher schools' administering. But as far as this is a broad topic requiring special attention, it wouldn't be developed in the present report.

Other countries' practice shows that a lot of $\mathrm{CoE}$ and $\mathrm{CoC}$ have already ceized to exist after research program's completion. In this sense, $\mathrm{CoE}$ and $\mathrm{CoC}$ are not eternal. They depend on the activity and initiatives of the management, on its flexibility, on the actuality and significance of scientific-research goals and tasks.

Centers of excellence and competence are more than just scientific infrastructure tools. They are a cause that opens new possibilities for quality research, for achieving international recognition and for improving the image of Bulgarian science. In order to be successful, however, they should be competently managed with participation of all interested parties.

\section{REFERENCE LIST}

Centers of Excellence (2018a). http://dg.dk/en/centers-of-excellence-2/.

Centers of Excellence in Research (2018b). http://www.aka.fi/en/research-and-science-policy/centres-ofexcellence/.

Center for Excellence in Research (2018c). https://research.usc.edu/about/vp/cer/.

Centres of Excellence in the Nordic countries, (2012a). Nordic Institute for Studies in Innovation, Research and Education (NIFU), 4/2012.

Dag Aksnes et all. (2012b). Centres of Excellence in the Nordic countries. Nordic Institute for Studies in Innovation, Research and Education (NIFU), 2012, p.8.

Etzkowitz, H., Leydesdorff, L. (1998a). The endless transition: A triple helix of universityindustry-government relations. Minerva, 36, 203-288, 1998.

Etzkowitz, H. (2000a). Tech transfer, incubators probed at triple helix III. Research Technology Management, 43(6): 4, 2000.

Gulbrandsen, M., Slipersaeter, S. (2007a). The third mission and the entrepreneurial university model. In: 
Bonaccorsi, A., Daraio, C. Universities and Strategic Knowledge Creation. Specialization and Performance in Europe. Cheltenham: Edward Elgar, 2007, pp. 112-143.

How to Build More Impactful Centers of Excellence, Industry Week, Jun, 17, 2014. (2018d). http://www.industryweek.com/operations/how-build-more-impactful-centers-excellence.

Miller, K., McAdam, M., McAdam, R. (2014a). The changing university business model: a stakeholder perspective, R\&D Management, 44, 3, 2014, p.265-287.

Lemola, T. (2002a). Convergence of national science and technology policies: the case of Finland. Research Policy 31 (2002) pp. 1481-1490 http://blogs.helsinki.fi/changingdynamics/files/2010/09/Lemola_Convergence_of_ST_policies.pdf.

RCUK Executive Directorate delivery plan 2016-2017. (2017a). http://www.rcuk.ac.uk/documents/documents/rcukexecutivedirectoratedeliveryplan-pdf/.

Road map to a Centre of Excellence. (2017b). A business white paper. https://www.hpe.com/h20195/v2/GetPDF.aspx/4AA2-4224EEW.pdf.

The Centre for Excellence in Teaching and Learning through Design CETLD. (2018e). http://arts.brighton.ac.uk/projects/cetld.

Analysis of the state of research in Bulgaria. (2010a), https://www.fni.bg/?q=node/20.

Europe 2020 - flagship initiatives: (2018f). http://ec.europa.eu/europe2020/europe-2020-in-anutshell/flagship-initiatives/index_bg.htm.

Izpalnenie na Plana za deystvie po ISIS. (2018g). (Изпълнение на Плана за действие по ИСИС), https://www.mi.government.bg/bg/themes/inovacionna-strategiya-za-inteligentna-specializaciya-narepublika-balgariya-2014-2020-g-i-proces-na-i-1470-287.html.

Inovatsionna strategiya za inteligentna spetsializatsiya: na Republika Balgariya (2018h). (Иновационна стратегия за интелигентна специализация: на Република България 2014-2020). https://www.mi.government.bg/bg/themes/inovacionna-strategiya-za-inteligentna-specializaciya-narepublika-balgariya-2014-2020-g-i-proces-na-i-1470-287.html.

Natsionalna programa za razvitie: Balgariya 2020. (2018i). (Национална програма за развитие: България 2020), http://www.strategy.bg/StrategicDocuments/View.aspx?ld=765.

Natsionalna patna karta na nauchnata infrastruktura, 2014. (2018j). (Национална пътна карта на научната инфрраструктура, 2014), http://www.strategy.bg/StrategicDocuments/View.aspx?ld=919.

Natsionalna strategiya za razvitie na nauchnite izsledvaniya 2020. (2018k). (Национална стратегия за развитие на научните изследвания 2020), http://www.strategy.bg/StrategicDocuments/View.aspx?lang=bg-BG\&ld=708.

Operativna programa „Nauka i obrazovanie za inteligenten rastezh“ 2014-2020. (2018I). (Оперативна програма „Наука и образование за интелигентен растеж“ 2014-2020), http://sf.mon.bg/?go=page\&pageld=36.

Strategiya „Evropa 2020“ (2018m). (Стратегия „Европа 2020“), http://ec.europa.eu/europe2020/index_bg.htm.

Strategiya za razvitie na vissheto obrazovanie v Republika Balgariya za perioda 2014 - 2020 g. (2018n). (Стратегия за развитие на висшето образование в Република България за периода 2014 - 2020 г.), http://www.strategy.bg/StrategicDocuments/View.aspx?ld=962.

Smart Specialisation Platform (20180). http://s3platform.jrc.ec.europa.eu/regions/PT?s3pv=1 . 